\title{
Intracranial hypertension causing visual failure in cryptococcus meningitis
}

\author{
C T TAN
}

From the Faculty of Medicine, University of Malaya, Kuala Lumpur, Malaysia

SUMMARY Thirty four patients with cryptococcal meningitis seen in the University of Malaya medical centre since 1980 were reviewed. Eleven patients had bilateral papilloedema and visual impairment but eventually survived. Seven patients had intensive aggressive measures, including shunting to reduce intracranial hypertension irrespective of ventricular size shown in CT scan, and showed substantial improvement in vision. It is concluded that papilloedema and visual failure in cryptococcal meningitis reflects raised intracranial pressure and that this should be treated vigorously.

Cryptococcal meningitis is the most commonly identified type of adult meningitis in the University Hospital, Kuala Lumpur. ${ }^{1}$ We have previously reported a high mortality $(30 \%)$. Eye signs, in particular papilloedema, were common but in the majority of the patients who developed papilloedema the CT scan did not show hydrocephalus. There was generally little correlation between CT scan changes and the clinical signs. Optic atrophy secondary to papilloedema and visual failure was the most important cause of morbidity among the survivors. ${ }^{1}$

Papilloedema and visual failure were common in other clinical series. ${ }^{2-6}$ Okun et al and others ${ }^{27}$ have demonstrated that cryptococcus may be deposited in the optic nerve and this may contribute to the visual abnormality. On the other hand, we have suggested that raised intracranial pressure is an important factor in causing optic atrophy and visual failure, even when hydrocephalus is not demonstrable by CT. ${ }^{1} \mathrm{We}$ report a preliminary assessment of the efficacy of treatment of papilloedema and visual failure, based on this hypothesis.

\section{Methods and results}

Thirty four consecutive patients with cryptococcal meningitis seen in the University of Malaya medical centre since 1980 were analysed. This period was chosen because CT scan became available in this hospital in 1980 and enabled easy assessment of the size of the ventricles. The first 20 patients were included in our previous review of the correlation between CT scan findings and clinical features. ${ }^{1}$ This study focuses on the visual failure and how its outcome was related to the treatment of raised intracranial pressure.

Received 6 July 1987.

Accepted 29 February 1988
There were 20 males and 14 females. The age during presentation ranged from 12 to 56 years with the average 33.6 years. The average duration of symptoms before diagnosis and treatment was 6.4 weeks. Eight of the patients had other diseases: diabetes mellitus, systemic lupus erythematosus, thyrotoxicosis (two cases each); fibrosing alveolitis, psoriasis on topical steroid (one case each). Seven patients had associated cryptococcoma of the chest.

Twenty three patients developed papilloedema, in $17 \mathrm{pa}-$ tients bilaterally. There were 10 deaths. Four of these cases had bilateral papilloedema which in two caused severe bilateral visual failure. These patients did not survive so that we could not assess the effect of treatment on vision. Among the patients who survived, 19 patients had papilloedema. Eleven of these had impairment of their visual acuity. The clinical details of these 11 patients are given in table 1 .

The 11 patients whose vision was impaired may be classified into four groups. In group A (cases 1,2) and B (cases 3,4 ) there was not a consistent effort to reduce the intracranial pressure when the ventricle was found to be of normal size. Shunts were inserted in the two patients in group B. In case 3, a lumbar-peritoneal shunt was inserted because of the presumptive diagnosis of benign intracranial hypertension. The papilloedema and visual acuity improved over the subsequent weeks. The shunt was noted to be blocked in 6 weeks. By then the papilloedema and visual failure had improved substantially and further measures were not taken to reduce the intracranial hypertension. In case 4 , the ventriculoperitoneal shunt was done only after considerable delay, when the blindness was well established. Group C (cases 5-8) and D (cases 9-11) were patients seen since the later part of 1984 , when there was a deliberate effort to reduce the intracranial pressure, irrespective of the ventricular size shown in the CT scan. The papilloedema and visual acuity were monitored closely. Lumbar puncture was done regularly to check the CSF pressure. If the visual acuity deteriorated, a trial of daily lumbar puncture was instituted. If this did not quickly improve, the patient was referred to a neurosurgeon and a shunting procedure done urgently, irrespective of the ventricular size shown in the CT scan. The 944 
Table 1 Clinical details of the 11 patients with visual impairment

\begin{tabular}{|c|c|c|c|c|c|c|c|c|}
\hline & $\begin{array}{l}\text { Age } \\
(y r)\end{array}$ & $\begin{array}{l}\text { Associated } \\
\text { disease }\end{array}$ & Fundi & $\begin{array}{l}\text { Visual } \\
\text { Acuity }\end{array}$ & $\begin{array}{l}\text { Other } \\
\text { cranial nerve } \\
\text { involvement }\end{array}$ & Outcome & $\begin{array}{l}\text { Shunt } \\
\text { Surgery }\end{array}$ & $\begin{array}{l}\text { Hydrocephalus } \\
\text { shown in CT } \\
\text { scan }\end{array}$ \\
\hline $\begin{array}{l}\text { Group } A \\
\text { (1) }\end{array}$ & 20 & Nil & $\begin{array}{l}\text { Bilateral } \\
\text { papilloedema }\end{array}$ & $\begin{array}{l}\text { Counting } \\
\text { finger (R) } \\
\text { Hand } \\
\text { movement (L) }\end{array}$ & Nil & $\begin{array}{l}\text { Counting } \\
\text { finger } \\
\text { bilateral }\end{array}$ & Nil & Mild \\
\hline (2) & 22 & Nil & $\begin{array}{l}\text { Bilateral } \\
\text { papilloedema }\end{array}$ & $\begin{array}{l}2 / 60(\mathrm{R}) \\
6 / 12(\mathrm{~L})\end{array}$ & $\begin{array}{l}\text { Bilateral } \\
\text { Abducen }\end{array}$ & Same & Nil & Nil \\
\hline $\begin{array}{l}\text { Group } B \\
\text { (3) }\end{array}$ & 25 & Nil & $\begin{array}{l}\text { Bilateral } \\
\text { papilloedema }\end{array}$ & Counting & Nil & $6 / 24$ both & $\begin{array}{l}\text { Lumboperiton- } \\
\text { eal shunt }\end{array}$ & Nil \\
\hline (4) & 37 & $\begin{array}{l}\text { Diabetes } \\
\text { mellitus }\end{array}$ & $\begin{array}{l}\text { Bilateral } \\
\text { papilloedema (mild) }\end{array}$ & $\begin{array}{l}\text { Blind } \\
\text { bilaterally }\end{array}$ & $\begin{array}{l}\text { Total } \\
\text { ophthalmo- } \\
\text { plegia } \\
\text { Facial nerve } \\
\text { (R) }\end{array}$ & Same & $\begin{array}{l}\text { Ventriculo- } \\
\text { peritoneal } \\
\text { shunt }\end{array}$ & Nil \\
\hline$\underset{\text { (5) }}{\text { Group } C}$ & 44 & $\begin{array}{l}\text { Diabetes } \\
\text { mellitus }\end{array}$ & $\begin{array}{l}\text { Papilloedema (R) } \\
\text { Old eye injury (L) }\end{array}$ & $6 / 60(R)$ & Nil & $6 / 24(R)$ & $\begin{array}{l}\text { Ventriculo- } \\
\text { peritoneal } \\
\text { shunt }\end{array}$ & Nil \\
\hline (6) & 13 & Nil & Papilloedema (R) & $\begin{array}{l}\text { Counting } \\
\text { finger }(R)\end{array}$ & Nil & $6 / 6$ & Nil & Nil \\
\hline (7) & 38 & Nil & $\begin{array}{l}\text { Bilateral } \\
\text { papilloedema }\end{array}$ & $\begin{array}{l}6 / 60(\mathrm{R}) \\
<6 / 60(\mathrm{~L})\end{array}$ & Nil & $\begin{array}{l}6 / 12(\mathrm{R}) \\
6 / 60(\mathrm{~L})\end{array}$ & $\begin{array}{l}\text { Ventriculo- } \\
\text { peritoneal } \\
\text { shunt }\end{array}$ & Moderate \\
\hline (8) & 13 & Nil & $\begin{array}{l}\text { Bilateral } \\
\text { papilloedema }\end{array}$ & $\begin{array}{l}\text { Counting } \\
\text { fingers } \\
\text { bilaterally }\end{array}$ & Nil & $6 / 9$ bilaterally & $\begin{array}{l}\text { Ventriculo- } \\
\text { peritoneal } \\
\text { shunt }\end{array}$ & Mild \\
\hline $\begin{array}{c}\text { Group D } \\
(9)\end{array}$ & 44 & Nil & $\begin{array}{l}\text { Bilateral } \\
\text { papilloedema }\end{array}$ & $6 / 24(R)$ & Nil & $6 / 6$ & Ventriculo- & Nil \\
\hline (10) & 38 & $\begin{array}{l}\text { Thyrotoxi- } \\
\text { cosis }\end{array}$ & Bil. papilloedema & $\begin{array}{l}6 / 18(\mathrm{R}) \\
6 / 12(\mathrm{~L})\end{array}$ & Nil & $6 / 9$ bilaterally & & Nil \\
\hline (11) & 12 & Nil & $\begin{array}{l}\text { Bilateral } \\
\text { papilloedema }\end{array}$ & $6 / 12$ bilaterally & Nil & $6 / 6$ bilaterally & $\begin{array}{l}\text { Ventriculo- } \\
\text { peritoneal } \\
\text { shunt }\end{array}$ & $\begin{array}{l}\text { Dilated } \\
\text { (R) temporal } \\
\text { horn }\end{array}$ \\
\hline
\end{tabular}

Group A: No active measures taken to reduce the intracranial pressure.

Group B: Some measures were taken to reduce the intracranial pressure.

Group C \& D: Active measures were taken to reduce the intracranial pressure.

initial visual loss in the group $\mathrm{C}$ patients was severe; in group $D$, it was mild. Table 2 is a summary of the results. As shown, the visual outcome was better in group $C$ patients as compared to group B and group A. All the patients in group D, whose visual loss was not severe, fully recovered their visual function.

\section{Discussion}

Our results support the importance of intracranial hypertension in causing papilloedema and visual failure in cryptococcal meningitis. Vigorous measures to reduce the intracranial pressure, including the use of

Table 2 A summary of the outcome of the 11 patients with visual impairment

\begin{tabular}{lll}
\hline & $\begin{array}{l}\text { No. of eyes improved/ } \\
\text { total no. of eyes with } \\
\text { visual impairment }\end{array}$ & $\begin{array}{l}\text { No. of patients improved/ } \\
\text { total no. of patients with } \\
\text { visual impairment }\end{array}$ \\
\hline Group A & $0 / 4$ & $0 / 2$ \\
Group B & $2 / 4$ & $1 / 2$ \\
Group C & $5 / 6$ & $4 / 4$ \\
Group D & $5 / 5$ & $3 / 3$ \\
\hline
\end{tabular}

shunting procedures irrespective of ventricular size, reversed the visual failure in most patients.

Although direct infiltration of the optic nerve occurs $^{2} 7$ it appears not to be so important as raised intracranial pressure in causing visual loss. The predilection for the third and sixth nerve involvement in addition to the second nerve also supported the important role of raised intracranial pressure. Eight patients had other cranial nerves involved; six had an abducen palsy, which in three patients was bilateral; three others had an oculomotor palsy; only two had a facial nerve palsy and one cochlear nerve involvement.

Visual failure often occurred bilaterally. The onset was often rapid over days with associated headache and vomiting and the symptoms quickly improved after lumbar punctures. On the other hand, Moore ${ }^{8}$ did bilateral nerve sheath decompression without helping a patient with cryptococcal meningitis with bilateral papilloedema and visual acuity of less than $6 / 60$. However, details of the duration of visual failure before surgery were not given. The cause of the intra- 
cranial hypertension, is uncertain. There was asymmetrical ventricular enlargement in case 11 , suggesting that blockage of CSF flow was important. In the other cases, the mechanisms contributing to the intracranial hypertension were not clear.

There has been substantial improvement in the mortality in our patients since 1984 . This may have been partly due to earlier diagnosis and the younger age of patients seen more recently. As well as the attention to lowering CSF pressure, there was also an effort to reduce steroid administration to a minimum. It is well recognised that the use of steroids is related to the development of cryptococcal meningitis as well as cryptococcaemia and continuing treatment is associated with a worse prognosis. ${ }^{89}$ The avoidance of steroids as far as possible probably helped to improve the outcome of treatment since 1984.

All cases seen since the latter part of 1984 were treated only with intravenous amphotericin and oral 5-fluorocytocine. By contrast, six of the patients in the earlier period were given IV/intraventricular/ intrathecal miconazole and two others were given intrathecal amphotericin, in addition to IV amphotericin and oral 5-fluorocytocine. Although there are reports that some cases respond to miconazole, usually after failed treatment with amphotericin and 5-fluorocytocine, ${ }^{1011}$ the role and efficacy of miconazole has still to be defined. ${ }^{12}$ It was for this reason that we have not used the drug in recent years.

We have previously shown that a number of patients have CT scan changes showing cerebral involvement, often without any clinical signs. ${ }^{1}$ Brain biopsies were done in cases 8 and 11, at the time surgical shunt procedures were carried out. We were surprised to find cryptococcus in brain tissues of both cases. Subclinical involvement of the brain may be more frequent than has been suspected. With the use of a subcutaneous reservoir, ${ }^{13}{ }^{14}$ anti-fungal drugs can be delivered directly into the ventricular CSF. This does not necessarily mean that the drug enters into the brain tissues effectively. It was for this reason that we have not used intrathecal and intraventricular routes in our cases since 1984 . Factors that contribute generally to improvement in the treatment of cryptococcal meningitis probably also indirectly improve the visual outcome.

\section{References}

1 Tan CT, Kuan BB. Cryptococcus meningitis, clinical-CT scan considerations. Neuroradiology 1987;29:43-46.

2 Okun E, Butler WT. Opthalmologic complication of cryptococcal meningitis. Arch Ophthalmol 1964;71:52-57.

3 Edwards VE, Sutherland JM, Tyrer JH. Cryptococcosis of the central nervous system. J Neurol Nuerosurg Psychiat 1970;33:415-25.

4 Richardson PM, Mohandas A, Arumugasamy N. Cerebral cryptococcosis in Malaysia. J Neurol Neurosurg Psychiatry 1976;39:330-7.

5 DeWytt CN, Dickson PL, Holt GW. Cryptococcal meningitis. J Neurol Sci 1982;53:283-92.

6 Tjia TL, Yeow YK, Tan CB. Cryptococcal meningitis. $J$ Neurol Neurosurg Psychiatry 1985;48:853-8.

7 Kupfer C, McDrane E. A possible cause of decreased vision in cryptococcal meningitis. Invest Opthalmol 1974;13:801-4.

8 Perfect JR, Durack DT, Gallis HA. Cryptococcemia. Medicine 1983;62:98-109

9 Dimond RD, Bennett MD. Prognostic factors in cryptococcal meningitis. Ann Int Med 1974;80:176-81.

10 Weinstein L, Jacoby I. Successful treatment of cerebral cryptococcoma and meningitis with miconazole. Ann Int Med 1980;93:569-71.

11 DeWytt C. Cryptococcal meningitis. Med J Aust 1981;1(10):525-6.

12 Bennett JE. Mecanazole in cryptococcosis and systemic candidiasis: a word of caution. Ann Int Med 1981;94:708-9.

13 Ommaya AK. Subcutaneous reservoir and pump for sterile access to ventricular cerebrospinal fluid. Lancet 1963;i:983-4.

14 Diamond RD, Bennett JE. A subcutaneous reservoir for intrathecal therapy of fungal meningitis. Engl $J$ Med 1971:288:186-8. 